\title{
Short Communication: Hepatoprotective effect of methanol extract of sambiloto leaves (Andrographis paniculata) against malondialdehyde levels in liver tissues of paracetamol-induced Wistar rat
}

\author{
ANDRIANI $^{1, \boldsymbol{v}}$, GUNTUR SUSENO $^{2}$, EFFIANA $^{3}$, VIRHAN NOVRIANY ${ }^{1}$, IIT FITRIANINGRUM ${ }^{4}$ \\ ${ }^{1}$ Department of Biochemistry, Faculty of Medicine, Universitas Tanjungpura. Jl. Prof. Hadari Nawawi, Pontianak 78124, West Kalimantan, Indonesia. \\ Tel.: $\pm 62-561-765392$, Fax.: $\pm 62-561-756399$, ”email: bundawiam_dr@yahoo.com, guntursuseno1@gmail.com \\ ${ }^{2}$ Department of Medical Science, Faculty of Medicine, Universitas Tanjungpura. Jl. Prof. Hadari Nawawi, Pontianak 78124, West Kalimantan, Indonesia \\ ${ }^{3}$ Department of Microbiology, Faculty of Medicine, Universitas Tanjungpura. J1. Prof. Hadari Nawawi, Pontianak 78124, West Kalimantan, Indonesia \\ ${ }^{4}$ Department of Pharmacology, Faculty of Medicine, Universitas Tanjungpura, Jl. Prof. Hadari Nawawi, Pontianak 78124, West Kalimantan, Indonesia
}

Manuscript received: 22 March 2018. Revision accepted: 30 April 2018.

\begin{abstract}
Andriani, Suseno G, Effiana, Novriany V, Fitrianingrum I. 2018. Short Communication: Hepatoprotective effect of methanol extract of sambiloto leaves (Andrographis paniculata) against malondialdehyde levels in liver tissues of paracetamol-induced Wistar rat. Nusantara Bioscience 10:87-90. Andrographis paniculata contains andrographolide and flavonoids, which have a hepatoprotective effect. This study was aimed to examine hepatoprotective effect of Andrographis paniculata extract against liver tissues malondialdehyde (MDA) levels of paracetamol induced Wistar rat (Rattus novegicus). The study was designed with posttest-only control group conducted at Tanjungpura University, Indonesia in June 2015. A total of 30 rats at age of three weeks were divided into 6 groups. They were given toxic dose paracetamol, curcumin and A. paniculata extract in different dose. Liver tissues were tested by Wills's method. The data was analyzed using One-way ANOVA and LSD Post-hoc test. MDA levels of liver tissues were i.e, normal control $\left(0.34 \mathrm{nmol} \mathrm{mL} L^{-1}\right)$, positive control $\left(0.34 \mathrm{nmol} \mathrm{mL}^{-1}\right)$, dose $1\left(0.45 \mathrm{nmol} \mathrm{mL} L^{-1}\right)$, dose $2\left(0.55 \mathrm{nmol} \mathrm{mL}^{-1}\right)$, dose $3\left(0.63 \mathrm{nmol} \mathrm{mL}^{-}\right.$ $\left.{ }^{1}\right)$, negative control $\left(1.32 \mathrm{nmol} \mathrm{mL}^{-1}\right)$. Result showed that MDA levels of liver tissues of negative control group were significantly different with other groups (ANOVA, $\mathrm{p} \leq 0.05$ ). There were no significant differences between MDA levels of liver tissues of Dose 1 with normal control and positive control (ANOVA, $\mathrm{p}>0.05$ ). The methanol extract of $A$. paniculata has a hepatoprotective effect in (MDA) levels of paracetamol-induced Rattus novegicus with an effective dose of $500 \mathrm{mg} \mathrm{kg}^{-1}$.
\end{abstract}

Keywords: Andrographis paniculata, hepatoprotective effect, malondialdehyde

\section{INTRODUCTION}

Inflammation is a protective response involving host cells, blood vessels, and proteins and other mediators to eliminate the initial cause of cell injury, and the necrotic cells and tissues because of the original insult, and to initiate the process of reparation. There are five local signs of inflammation, i.e., calor, rubor, tumor, dolor and functio laesa (Kumar et al. 2013). One of drugs that can be used to alleviate the symptoms of inflammation and freely available in Indonesia is paracetamol. Paracetamol has replaced aspirin as a first-line in alleviating inflammatory pain. However, the use of paracetamol in large doses can result in toxic effects and induce hepatic disease (druginduced liver disease/DILD). Hepatotoxicity may occur when the use of paracetamol is more than $4000 \mathrm{mg}$ per day or more than $2000 \mathrm{mg}$ per day for alcoholic patients (Brunton et al. 2005).

Liver diseases are a public health problem in Indonesia. According to data from the Ministry of Health of the Republic of Indonesia, the number of cases of liver diseases in Indonesia ranks third after infectious diseases and pulmonary diseases. There are about 2,000 cases of acute liver failure that occurs in every year; $50 \%$ of them are caused by drug toxicity, $39 \%$ due to paracetamol, $13 \%$ due to idiosyncratic reaction and $8 \%$ due to other medications (Indonesian Health Development and Research 2013).

Hepatotoxicity occurs because of toxic compounds resulting from metabolism of paracetamol, N-acetyl-pbenzo-quinoneimine (NAPQI), by cytochrome P4502E1 (CYP2E1). In normal conditions, NAPQI was detoxified by conjugation with glutathione (GSH) as an endogenous antioxidant. As consequence, conjugation will result in decreases of hepatocellular GSH leading to GSH deficiency in which free-NAPQI will covalently bind to liver cell macromolecules such as lipids and cell membrane proteins that cause liver cell damage and generates freeradical compounds (Rang et al. 2016).

Free radicals are defined as atoms or molecules that have unpaired electrons in their outermost orbital. These unpaired electrons are highly reactive to bond with other electrons. The lipid peroxidation process will occur when free radicals meet with polyunsaturated fatty acids. This lipid peroxidation process produces several compounds such as malondialdehyde (MDA). Excessive amounts of free radicals increase the process of lipid peroxidation resulting in increase of MDA production. Therefore, MDA 
levels detected from the liver tissue can be used as a marker of tissue damage due to oxidative stress (Yustika et al. 2013).

Andrographis paniculata containing andrographolide and flavonoids are proven efficacious to improve liver cell function. Andrographolide and flavonoids act as antioxidants and scavenger agents inhibit lipid peroxidation that can be demonstrated by decreasing MDA levels as lipid peroxidation products. Therefore, this study was aimed to examine the hepatoprotective effect of methanol extract of $A$. paniculata and to compare the hepatoprotective effect of methanol extract of $A$. paniculata with curcumin as a substance known as hepatoprotectant (Goenarwo et al. 2010).

\section{MATERIALS AND METHODS}

\section{Procedures}

This research is experimental research conducted in Biochemistry Laboratorium of Faculty Medicine, Tanjungpura University, Indonesia in June 2015. The study was designed with post-test only with control group. A total of 30 rats at age of three weeks were involved in this study obtained from a certified rat farm named "D-Citirat" in Pontianak, Indonesia with certificate number 24/NRSH/X/2015.

Rats were divided into 6 groups, i.e., normal control group, positive control, negative control, dose 1, dose 2, and dose 3. All groups (except normal control group) were given paracetamol $\left(900 \mathrm{mg} \mathrm{kg}^{-1}\right)$ to induce hepatic damage. Normal control group received no treatment, the positive control group was given curcumin (500 mg kg-1), the negative control group received paracetamol alone, the dose 1 group was given methanol extract of A. paniculata (500 $\mathrm{mg} \mathrm{kg}^{-1}$ ), the dose 2 group was given methanol extract of A. paniculata $\left(1000 \mathrm{mg} \mathrm{kg}^{-1}\right)$, the dose 3 group was given methanol extract of A. paniculata $\left(2000 \mathrm{mg} \mathrm{kg}^{-1}\right)$. Adaptation period is given for 7 days and treatment is given for the next 7 days, then the liver tissue was collected. MDA in hepatic tissue homogenates was tested by Wills method.

\section{Data analysis}

Data were analyzed statistically using One-way ANOVA test and LSD post hoc test. This research was done after passed through the ethical review from the department of research ethics of Medical Faculty of Tanjungpura University, Pontianak, West Kalimantan, Indonesia (481/UN22.9/DT/2015).

\section{RESULTS AND DISCUSSION}

The statistical test showed normal distributed data (Shapiro Wilk p> 0.05), homogeneous data variance (Homogeneity Test of Variance $p>0.05$ ) and ANOVA ( $p=$ 0.000 ) then by Post Hoc Test LSD analysis of $95 \%$ confidence obtained value between groups. The mean value of MDA levels of mice liver tissue sequentially from highest to lowest is negative control $(1.32 \pm 0.21)$, dose 3 $(0.63 \pm 0.06)$, dose $2(0.55 \pm 0.08)$, dose $1(0.45 \pm 0.07)$, positive control $(0.34 \pm 0.06)$ and normal control $(0.33 \pm$ 0.07) (Table 1).

The negative control group had the highest MDA levels of the hepatic tissue compared to the other group with the mean value of MDA was $1.37 \pm 0.23 \mathrm{nmol} \mathrm{mL}$. The statistical test performed on the mean MDA levels of the negative control group had statistically significant differences over all other groups (Post Hoc Test LSD, p $<0.05$ ).

MDA levels of hepatic tissue of positive control group were higher than MDA levels of the Normal control group. However, MDA levels of hepatic tissue of positive control group was lower when it was compared to the dose 1, dose 2 , dose 3, and negative control groups. The statistical test of MDA levels of hepatic group of positive control group showed that significant differences with the negative control group, dose 2, and dose 3 (Post Hoc Test LSD, p $<0.05$ ), where the mean MDA levels of hepatic group of positive control group $\left(0.33 \pm 0.06 \mathrm{nmol} \mathrm{mL}^{-1}\right)$ were lower than that in control negative, dose 2 , and dose 3 . the statistical test also showed no significant difference between positive control group and normal control $(0.32 \pm$ 0.07 ) and dose 1 (Post Hoc Test LSD, p> 0.05).

Table 1. Mean values of MDA levels in liver tissues

\begin{tabular}{cc}
\hline Group & $\begin{array}{c}\text { MDA levels in liver tissues in }\left(\mathbf{n m o l ~} \mathbf{~ m L}^{\mathbf{- 1}}\right) \\
\text { homogenat }(\text { Mean } \pm \text { SD) }\end{array}$ \\
\hline $\mathrm{KN}$ & $0.34 \pm 0.07$ \\
$\mathrm{~K} \pm$ & $0.34 \pm 0.06$ \\
$\mathrm{~K}-$ & $1.32 \pm 0.21$ \\
$\mathrm{D} 1$ & $0.45 \pm 0.07$ \\
$\mathrm{D} 2$ & $0.55 \pm 0.08$ \\
$\mathrm{D} 3$ & $0.63 \pm 0.06$ \\
\hline
\end{tabular}

Note: $\mathrm{KN}=$ Normal group, $\mathrm{K}-=$ Negatif control group, $\mathrm{K} \pm=$ Positif control group, D1 : Dose 1 group, D2: Dose 2 group, D3: Dose 3 group

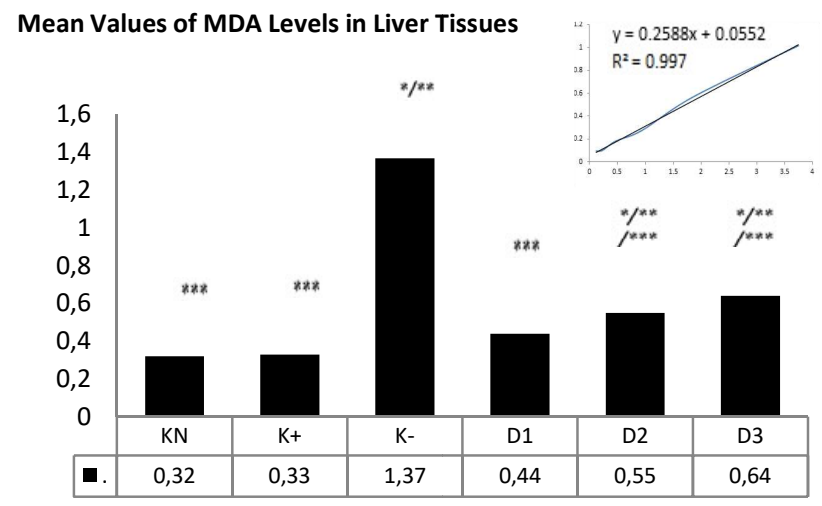

Figure 1. Mean values of MDA levels in liver tissues. $\mathrm{KN}=$ Normal group, $\mathrm{K}-=$ Negatif control group, $\mathrm{K} \pm=$ Positif control group, D1 : Dose 1 group, D2: Dose 2 group, D3: Dose 3 group. (One Way ANOVA, $\mathrm{p}=0.000) ;{ }^{*}$ Post Hoc Test LSD ( $<<0.05$ vs $\mathrm{K} \pm) ; * *$ Post Hoc Test LSD ( $<<0.05$ vs $\mathrm{KN}) ; * * *$ Post Hoc Test $L S D(\mathrm{p}<0.05$ vs K-) 
Mean of MDA level of group liver tissue dose 1 was higher than positive control group and neutral control, that was $0.59 \pm 0.09 \mathrm{nmol} \mathrm{L}^{-1}$, the mean of MDA group dose 1 was lower than dose 2 , dose 3 , and control negative. A statistically significant difference was also found between the dose 1 group and the negative control group and the dose 3 (Post Hoc Test LSD, $\mathrm{p}<0.05$ ). The statistical test also showed no significant difference (Post Hoc Test LSD, $\mathrm{p}>0.05)$ between dose 1 group and dose 2, normal control $\left(0.32 \pm 0.07 \mathrm{nmol} \mathrm{mL}^{-1}\right)$ and positive control $(0.52 \pm 0.06$ nmol $\left.\mathrm{mL}^{-1}\right)$.

Mean dose 2 levels of MDA of group dose 2 tissue of $0.55 \pm 0.08 \mathrm{nmol} \mathrm{mL}^{-1}$, lower than the dose 3 and negative control group, but higher than that in the normal control group, positive control and dose 1. The statistical test performed on average MDA levels Dose 2 group liver tissue showed no statistically significant difference between dose 2 group and dose 3 and Post DHL, p>0.05). However, statistically significant differences were found to the negative control group, positive control and normal control (Post Hoc Test LSD, p <0.05) with dose 2 had mean MDA hepatic tissue levels higher than that in the normal and positive controls, but it was compared with that in the negative control group.

The mean rate of MDA of group dose 3 liver tissue was $0.64 \pm 0.07 \mathrm{nmol} \mathrm{mL}^{-1}$, lower than in the negative control group, but higher than in the positive control group, normal controls, doses 1 and doses 2 . Statistical tests performed on average of MDA levels of hepatic tissue group dose 3 showed statistically significant differences over all other groups other than the dose 2 (Post Hoc Test LSD, p <0.05) group.

\section{Discussion}

Paracetamol induction in the negative control group without any hepatoprotector substance was conducted to show the lipid peroxidation process due to the oxidative stress occurring in paracetamol hepatotoxicity. The treatment of paracetamol as much as $900 \mathrm{mg} \mathrm{kg}^{-1}$ was induced by administering it solely to be able to give toxic effect. The MDA level of the negative control group was significantly different and had a higher value when it was compared with the normal control group. This happened because antioxidant defense mechanisms failed to prevent the formation of excessive ROS. This proves that paracetamol in toxic doses will trigger oxidative stress in hepatic tissue leading to lipid peroxidation and resulting in MDA products. The oxidative stress is caused by the metabolic process of paracetamol in the liver by CYP450 mainly by the enzyme CYP2E1 which causes the formation of intermediate compounds in the form of reactive NAPQI. NAPQI will form covalent bonds with intracellular proteins and disrupt intracellular function such as the decrease amount of calcium ions in the cytosol leading to lipid peroxidation of the membrane which finally causes cell death (Basu et al. 2012).

MDA levels in the negative control group were significantly higher than those in positive control. This shows that oxidative damage is attenuated by the administration of curcumin. Curcumin is a scavenger agent, which can protect the tissue from free radicals generated from oxidative stress; thus, lipid peroxidation and cell membrane damage were limited (Somnawat et al. 2013).

MDA levels in liver tissues of rats in dose 1, dose 2, and dose 3 group were significantly lower and different than those in the negative control group. Based on this, it can be concluded that the methanol extract of A.paniculata has hepatoprotective effect by inhibiting free radical in paracetamol-induced rats, which could be observed from the decreased levels of MDA in liver tissues as lipid peroxidation products due to oxidative stress. This condition is in accordance with Bardi et al. (2014) who reported that the administration of methanol extract of $A$. paniculata at a dosage of $500 \mathrm{mg} \mathrm{kg-1}$ significantly decreased MDA levels of liver tissues of thioacetamideinduced rats.

Hepatoprotective effect of methanol extract of $A$. paniculata is caused by 2 active substances contained in $A$. paniculata, namely andrographolide and flavonoids. Kamdem and Ho (2002) conducted a study of the active compound of andrographolide. Andrographolide is the main active substance in the $A$. paniculata that works by acting as an exogenous antioxidant. Andrographolide has aliphatic hydrogen groups on $\mathrm{C}-11$ carbon atoms which can act as a hydrogen donor to pair with unpaired electrons from free radicals. In other words, andrographolide acts as a free radical scavenger breaking the lipid peroxidation chain in a series of oxidative stresses causing decreased levels of MDA as a product of lipid peroxidation.

Flavonoids decrease MDA levels of liver tissue by working as exogenous antioxidants and increasing endogenous antioxidant biosynthesis. Flavonoids are known as an antioxidant, which can inhibit cell damage due to paracetamol metabolism. Flavonoids have hydroxyl phenolic $(\mathrm{OH})$ groups in their molecular structure, which have the role of alic hydrogen groups in andrographolide. The $\mathrm{OH}$ group acts as a free radical scavenger agent because it attracts free radicals. $\mathrm{OH}$ groups in flavonoid compounds will replace endogenous GSH antioxidants that have been depleted by free radicals due to toxic doses of paracetamol. The $\mathrm{OH}$ group on flavonoids will help conjugate paracetamol into mercapturic acid and convert NAPQI into a hydrophilic non-active metabolite so that it is easily excreted through urine (Yousef et al. 2010). Flavonoids play a role in GSH biosynthesis through de novo pathway by stimulating GCL gene expression that acts as a catalyst and modulator GSH formation by de novo. MDA levels as lipid peroxidation products decline because of the oxidative stress mechanism inhibited by increased production of endogenous antioxidants GSH (Mari and Nieto 2003).

The effective dose of this study was done from the smallest dose group that had the effect and approached the positive control group. in this study, it was found that in the dose 1 group, MDA levels of liver tissue were not significantly different with the positive control group. So it can be concluded that the effective dose in this study is 500 $\mathrm{mg} \mathrm{kg}{ }^{-1}$ of methanol extract of $A$. paniculata.

Methanol extract of $A$. paniculata has a hepatoprotective effect, which was proven by the decreased 
levels of MDA in liver tissues of paracetamol-induced Wistar rat (Rattus norvegicus). The effective dosage of methanol extract of $A$. paniculata in this study was $500 \mathrm{mg}$ $\mathrm{kg}^{-1}$. However, further studies on $A$. paniculata extract as a hepatoprotective agent are required so that it can be used for phytotherapy agent, especially study on hepatoprotective effect on the isolated andrographolide.

\section{ACKNOWLEDGEMENTS}

We would like to thank Research Department of Tanjungpura University who funds this research. We also would like to thank Biochemistry Department of Faculty Medicine of Tajungpura University, Pontianak, Indonesia who encouraged the authors to do molecular work.

\section{REFERENCES}

Bardi DA, Halabi MF, Hassandarvish P, Rouhollahi E, Paydar M, Moghadamtousi SZ, et al. 2014. Andrographis paniculata leaf extract prevents thioacetamide-induced liver cirrhosis in rats. PLoS One 9 (10): e109424. DOI: 10.1371/journal.pone.0109424.

Basu S, Haldar N, Bhattacharya S, Biswas S, Biswas M. 2012 Hepatoprotective activity of Litchi chinensis leaves against paracetamol-induced liver damage in rats. Amer-Eur J Sci Res 7 (2): $77-81$.
Brunton L, Lazo J, Parker K. 2005. Goodman \& Gilman's The Pharmacological Basis of Therapeutics. McGraw Hill, New York

Goenarwo E, Chodidjah, Kusuma R. 2010. The difference in SGOT level between boiled aqueous extract of Sendok (Plantago major) and sambiloto (Andrographis paniculata Ness) leave experimental study in male Wistar rats induced with paracetamol. Jurnal Sains Medika 2 (1): 41-45. [Indonesian]

Indonesian Health Development and Research. 2013. Basic Health Research. Indonesian Ministry of Health, Jakarta. [Indonesian]

Kamdem RE, Ho CT. 2002. Mechanism of the superoxide scavenging activity of neoandrographolide: A natural product from Andrographis paniculata Nees. J Agric Food Chem 50 (16): 4662-4665.

Kumar V, Abbas AK, Aster JC. 2013. Robbins Basic Pathology, 9th ed. Elsevier-Saunders, Philadelphia.

Mari M, Nieto N. 2003. Cytochrome P450 2E1 responsiveness in the promoter of glutamate-cysteine ligase catalytic subunit. J Hepatol 37 (1): 96-106.

Rang HP, Dale MM, Ritter JM, Flower RJ. 2016. Rang and Dale's Pharmacology 8th, ed. Elsevier's Health Sciences Rights Department, London.

Somanawat K, Thong-Ngam D, Klaikeaw N. 2013. Curcumin attenuated paracetamol overdose induced hepatitis. World J Gastroenterol 9 (12): 1962-1967.

Yousef ML, Omar SAM, El-Guendi MI, Abdelmegid LA. 2010. Potential protective effects of quercetin and curcumin on paracetamol-induced histological changes, oxidative stress, impaired liver and kidney functions and haematotoxicity in rat. Food Chem Toxicol 48 (11): 3246-3261.

Yustika AR, Aulanni'am, Prasetyawan S. 2013. Malondialdehyde (MDA) levels and histopathological images of Rattus norvegicus kidney post cyclosporine-A induction. Kimia Student Journal 1 (2): 222-228. [Indonesian] 